BADAN PENDIDIKAN DAN PELATIHAN KEUANGAN KEMENTERIAN KEUANGAN REPUBLIK INDONESIA

\section{JURNAL BPPK}

\title{
DOES CORRUPTION AFFECT POVERTY IN INDONESIA?
}

Azwar a, Rahmaluddin Saragih ${ }^{\mathrm{b}}$

a Balai Diklat Keuangan Makassar, Jalan Urip Sumoharjo Km. 4 Makassar 90234, Indonesia]

Email: azwar.iskandar@gmail.com (penulis berkorespondensi)

b Balai Diklat Keuangan Makassar, Jalan Urip Sumoharjo Km. 4 Makassar 90234, Indonesia]

Email: rsaragih@gmail.com

\section{ARTICLE INFORMATION}

ARTICLE HISTORY

Received

25 May 2018

Accepted to be published 16 August 2018

KEYWORDS:

corruption,

poverty

$A R D L$,

ECM

\section{ABSTRACT}

Korupsi kerap meningkatkan tingkat kemiskinan karena korupsi dapat mengurangi potensi pendapatan masyarakat miskin. Oleh karenanya, pemberantasan korupsi adalah sebuah isu penting dalam upaya pemberantasan kemiskinan. Penelitian ini dilakukan dengan tujuan untuk menganalisis dan menginvestigasi hubungan jangka pendak dan jangka panjang antara korupsi dan kemiskinan di Indonesia. Penelitian ini menggunakan data sekunder dari Bank Dunia dan Transparency International dan teknik Autoregressive Distributed Lag (ARDL) dan dynamic Error Correction Model (ECM) dengan menggunakan data headcount poverty index periode tahun 1995-2017. Hasil penelitian mengindikasikan adanya hubungan posistif jangka pangka yang signifikan antara korupsi dan kemiskinan di Indonesia. Dalam jangka panjang, kenaikan 1\% indeks korupsi, menyebabkan kenaikan 1,36\% rasio kemiskinan. Implikasi negatif korupsi terhadap kehidupan masyarakat adalah sebuah bahaya yang besar dalam kelangsungan dan perkembangan ekonomi nasional dan masyarakat. Hasil analisis simple pearson correlation juga menunjukkan bahwa korupsi memiliki konsekuensi distribusional yang signifikan melalui dampaknya terhadap belanja pemerintah. Tingginya tingkat korupsi mengakibatkan peningkatan tingkat kemiskinan dengan menurunkan efektifitas pertumbuhan ekonomi dan belanja pemerintah (pendidikan dan kesehatan). Untuk mengatasi hal ini, pemerintah seyogyanya mengupayakan berbagai kebijakan yang efektif dalam pemberatasan korupsi agar sumber-sumber kesejahteraan masyarakat seperti kekayaan alam, fasilitas pendidikan dan kesehatan, serta infrastruktur dapat dinikmati secara optimal oleh masyarakat.

Corruption is likely to increase poverty because it reduces the potential income earning of the poor. Therefore, eradicating corruption is a crucial issue in the poverty reduction process. This study is set out to investigate and analyze the short and long-run relationship between corruption and poverty. It uses secondary data from World Bank and Transparency International then using Autoregressive Distributed Lag (ARDL) and dynamic Error Correction Model (ECM), focuses on headcount poverty index during year 1995-2017. The results of study indicated that corruption has positive significant effect on the level of poverty ratio in 1\% significance level in the long run. This implies that in the long run, 1\% increase in corruption would increase the poverty ratio by $1.36 \%$. The negative implication of corruption on the life of the citizens is a major disaster in the economy and harmful to the growth and development of the citizens in particular and the economy in general. The simple pearson correlation findings also show that corruption has significant distributional consequences by affecting growth and government expenditures. High and rising corruption increases poverty by reducing the level and effectiveness of growth and social spending (education and health). For effective sustainable and management of this disaster, government should embark on policies that will reduce the level of corruption significantly so as to have positive influence on the standard of living of the citizens in terms of quality and efficient education, sound management of natural resources, provision of good health facilities and other infrastructures that will transcend to the growth of the economy. 


\section{INTRODUCTION}

An increasing number of empirical studies e.g. Knack and Keefer (1995), Mauro (1997), Keefer and Knack (1997), Mo (2001), and Keefer (2004) present persuasive evidence regarding the detrimental effects of corruption on various economic variables such as poverty and income inequality.

Corruption represents a common issue globally. The Corruption Perception Index (CPI), published annually by Transparency International (TI) since 1995 , has been widely credited for raising the issue of corruption to the international policy agenda. The CPI ranks approximately 180 countries/territories based on how corrupt their public sector is perceived, allotting scores between 0 and 100 , where 0 means that a country is perceived as highly corrupt, while 100 means it is perceived as very clean. According to the CPI 2017, Indonesia ranks 96th, with a score of 37; being perceived as more corrupt than other Asia Pacific countries such as Japan (ranking 20th, with a score of 73), Taiwan (ranking 29th, with a score of 63) and Malaysia (ranking 62th, with a score of 47), but less corrupt than Thailand, Mongolia, Vietnam, and the Philippines. While no country has received a perfect score (100), more than $70 \%$ of countries score below 60 , indicating a serious corruption problem ${ }^{1}$.

Corruption does not only affect the growth rate of income but also affects income inequality and poverty. The benefits of corruption are likely to accrue to the better connected individuals, who belong mostly to high income groups (Gupta et. al. 2002). According to Johnston (1989), corruption favors the 'haves' rather than the 'have nots' particularly if the stakes are large. The burden of corruption falls disproportionately on low income individuals. Individuals who belong to low income group to pay a higher proportion of their income than the individuals that belong to high income groups. As Tanzi (1998) argues, corruption distorts the redistributive role of government. Since only the better connected individuals get the most profitable government projects, it is less likely that the government is able to improve the distribution of income and make the economic system more equitable. It diverts government spending away from projects that benefit mostly low income individuals such as education and health to, for example, defense projects that create opportunities for corruption (Chetwyn et al., 2003).

Nevertheless, there are only a few empirical studies (Li, Xu, and Zou, 2000, Gupta et. al. 2002, and Chong and Calderon, 2000a, 2000b) analyzing the effects of corruption on income inequality and poverty. Using data from a mixed group of countries, i.e., low, middle, and high-income, $\mathrm{Li}, \mathrm{Xu}$, and $\mathrm{Zou}$ (2000) and Chong and Calderon (2000a) find an inverse U-shaped relationship between corruption and income inequality. They find a positive relationship between corruption and income inequality in high-income countries and a negative relationship in low-income countries. Gupta et al. (2002), on the other hand, using a smaller sample of countries, find a positive and linear relationship between corruption and income inequality. Chong and Calderon (2000b) and Gupta et al. (2002) both analyze the effects of corruption on poverty as well as on income inequality. As Chong and Calderon (2000b) argue, an increase in income inequality as corruption increases does not necessarily mean that poverty also increases. If, for example, the incomes in the higher end of the distribution grow faster than incomes in the lower end of the distribution, income inequality increases while poverty decreases. Both Chong and Calderon (2000b) and Gupta et al. (2002) find a positive and linear relationship between corruption and poverty.

The empirical literature on corruption gradually emerging in this decade suggests a negative relationship between corruption and growth. Mauro (1995), the first to look at how corruption affects growth in a cross-country sample, concludes that corruption causes slower growth. The main instrument for corruption in the growth equation, the ethno linguistic fracturization, however, has been shown to be a significant determinant of growth, both directly and indirectly (through other policy variables) (Easterly and Levine, 1997). Thus it no longer serves as a valid instrument for corruption in the growth regression. Using a cross-country sample, Murphy, Shleifer, and Vishney (1991) find that a larger rentseeking sector, as proxie by the ratio of college enrollments in law to total college enrollments, is associated with a lower growth rate. Knack and Keefer (1995) find that the quality of government institutions, including the degree of corruption, affects investment and growth as much as other political economy variables (e.g., political freedom, civil liberties, and political violence). Kaufman and Wei (1998) find that firms that pay more bribes also spend more time with bureaucrats in more corrupt countries and have a higher cost of capital, thus countering the view of corruption as "grease money." Finally, transitional countries are likely to have a smaller unofficial economy where taxes are fairer and regulation is less (Johnson, Kaufman, and Shleifer, 1997).

Poverty is obviously about more than insufficient income. It is also related to the access to and quality of public services vital to the poor such as health, education, water, infrastructures and sanitation. It is also about lack of opportunities, lack of access to information, lack of voice and lack of representation. The relationship between corruption and poverty is complex. In macroeconomic level, corruption affects poverty through lowering economic growth, reducing foreign and domestic investment, distorting market, 
hindering competition, and increasing income inequalities (Chetwynd et al., 2003). Corruption is likely to increase poverty because it reduces the potential income earning of the poor. Therefore, eradicating corruption is a crucial issue in the poverty reduction process. Alternatively, poverty which is usually indicated by low income, low education and health, vulnerability and powerlessness, invites corruption. Social and income inequalities in poor countries make greater imbalances in the distribution of power and encourage corruption (Ndikumana, 2006). A rational agent will be corrupt as long as the private income gained from corruption is equal or outweighs its private cost, because it will improve his/her welfare (Yaru and Aminu, 2009).

Although the link between corruption and poverty is often noted, the question of whether a short and long-run relationship exists between corruption and poverty has received less attention especially for Indonesia case. In other words, most of the studies which have investigated the link between corruption and poverty may conclude on causality in models that only show correlation. Thus, the policy recommendation for fighting against poverty and corruption can simply be wrong. Taking it to the limit, particularly for Indonesia, how good is it to try to decrease corruption by implementing anti-poverty strategies if the high poverty level is simply caused by high corruption and not the other way around? As we know, based on the Survey of Transparency International Corruption Perception Index (CPI) in 2017 (see Figure 1), Indonesia laced on the group of worst level of the corrupted countries in the Asia Pacific.

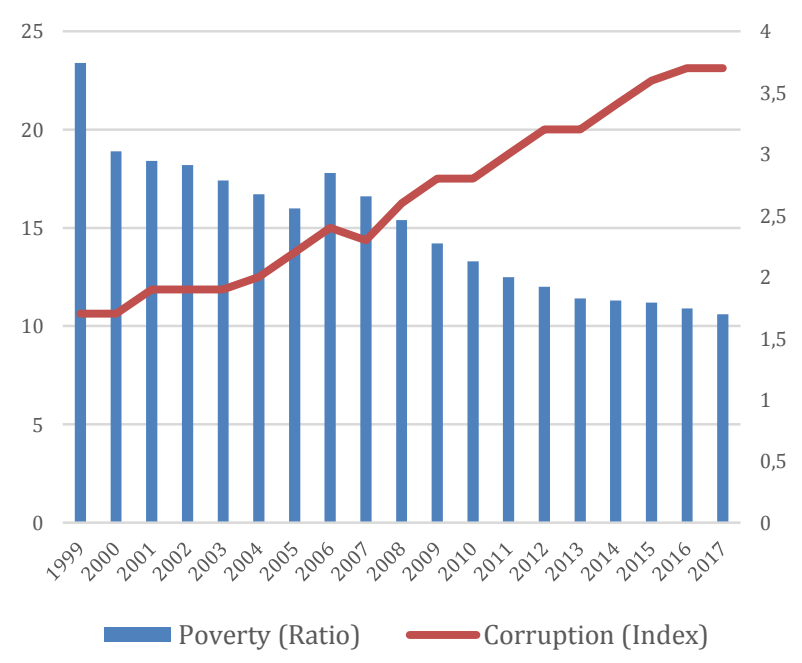

Source: World Bank dan Transparency International

Figure 1. Headcount Poverty Ratio and Corruption Perception Index

On the other side, for the last of decades, Indonesia has been experiencing a modest reduction in the rate of poverty. Based on the latest data from Indonesia's Statistics Agency (BPS), Indonesia's absolute poverty rose to 27.77 million people in March 2017 from 27.76 million in September 2016. However, the country's relative poverty figure fell to 10.64 percent of the population in March 2017 from 10.70 percent in September 2016. This seeming paradox - rising absolute poverty but falling relative poverty - is caused by Indonesia's growing population. Therefore, this study is set out to investigate and analyze the short and long-run between corruption and poverty. It uses Autoregressive Distributed Lag (ARDL) and dynamic Error Correction Model (ECM), focuses on capability poverty using headcount poverty index during year 1995-2017.

The findings of this study will be necessary to be able to get a clear picture of the extent of the problem of corruption and poverty in Indonesia and shall analyze and determine the connection or contribution of corruption to the problem of increasing poverty in Indonesia. The findings shall also be useful for policy makers and the general public not only for the purpose of creating awareness of the adverse effects of corruption on economic growth and income growth of the poor but also for utilising the data in policy formulation and implementation.

\section{LITERATURE REVIEW}

The theoretical and empirical literature on the relationship between corruption and poverty has been developed from the mid-1990s. Some non-government organizations such as TI which have focused on the problems of corruption and the rights of citizens to participate in political, economic and social development processes and corruption indices have produced. International organizations such as International Monetary Fund (IMF) and World Bank have also played a growing role to help countries in overcoming corruption.

The theoretical propositions for the relationship between corruption and income inequality also arise from rent theory and the ideas of Rose-Ackerman (1978) and Krueger (1974). Corruption causes some groups and individuals permanently benefit more, the distributional effects of corruption are more rigid as the corruption continues and it is a function of government sharing in resource allocation (Gupta et al., 1998).

These theoretical propositions on the relationship between corruption and poverty are supported by numerous empirical studies. In a cross national analysis of the channels through which corruption adversely affects income distribution and poverty, Gupta et al. (1998) specified an inequality model using Gini coefficient to measure income inequality and several indices of corruption. In their study, they ascertained that increasing income inequality due to corruption reduce economic growth and thereby aggravate poverty. They also found that tax evasion and its exemption in favor of wealthy elites can reduce the tax base and leads to more income inequality as 
well as diverting benefits of poverty reduction measures due to poor targeting of social programs.

Dabla-Norris and Wade (2002) propose a theoretical model to explain why the rich tend to focus on gaining income from corrupt activities. Individuals face a fixed cost when they are looking for gains from corruption through government employment but not into productive activity. Another motivation for the rich to enter the corrupt government bureaucracy is that they can protect their own wealth from the corrupt appropriative activities of other government officials. So the model contains both supply and demand side reasons for why corrupt government is the domain of the wealthy. The poor are productive and are the martyr. The model is motivated by evidence that the rich in poor countries tend to keep themselves and their families in government employment and in control of government. Government officials also often have family businesses that are related to the officials' fields of authority.

You and Khagram (2005) believe that income inequality also increase the level of corruption through material and normative mechanisms. Their analysis of 129 countries using 2SLS methods with different instrumental variables supports their hypotheses using different measures of corruption. Because income inequality also contributes to corruption, societies often fall into vicious circles of inequality and corruption.

Dincer and Gunalp (2008) analyzed the impact of corruption on income inequality and poverty in the United States using an objective measure of corruption, different measures of inequality and income poverty, time series and cross sectional data. The results show robustly that increasing corruption leads to increases income inequality and poverty.

Income inequality and poverty is affected by corruption through various channels including overall growth, biased tax systems and poor targeting of social programs as well as through its impact on asset ownership, human capital formation, education inequalities and uncertainty in factor accumulation.

High poverty is as a result of high corruption for two reasons. First, evidence suggests that a higher growth rate of the economy is associated with a higher rate of poverty reduction (Ravallion and Shaohua, 1997), and that corruption slows the rate of poverty reduction by reducing growth. Second, income inequality has been shown to be harmful to growth (Alesina and Dani, 1994; Persson and Guido, 1994), and if corruption increases income inequality, it will also reduce growth and thereby limit poverty reduction (Ravallion, 1997).

Corruption can lead to tax evasion, poor tax administration, and exemptions that disproportionately favor the well-connected and wealthy population groups. This can reduce the tax base and the progressivity of the tax system, possibly leading to increased income inequality. Various studies show that corruption lowers investment and consequently economic growth (Mauro,1995, Knack and Philip, 1996). A paper by Tanzi (1998) provides evidence that corruption actually increases public investment, especially investment in unproductive projects and squeezes expenditure allocations for operations and maintenance, thereby lowering the productivity of the public stock.

The targeting of social programs to the truly needy can be affected by corruption. The use of government-funded programs to extend benefits to relatively wealthy population groups, or the siphoning of funds of poverty-alleviation programs by wellconnected individuals, will diminish the impact on social programs on income distribution and poverty (Laban and Sturzenegger, 1994).

Furthermore, corruption is an economic, legal, environmental and social issue. It is defined by Transparency International as the abuse of power for private advantage. Corruption could be viewed as the misuse of public office for private gain; this includes but not limited to: embezzlement, nepotism, bribery, extortion, influence peddling and fraud. Hoffman (2012) described corruption in the public sector more simplistically as "theft from the poor". Thus, corruption may result in enriching government officials as well as private individuals who obtain a large share of public benefits or bear a lower share of public costs. By so doing, corruption distorts government's role in resource allocation, and this may be detrimental to the poor (Gupta, Davoodia and Alonso-Terme, 2002).

In the same vein, corruption has the capacity to render any society unstable and insecure, especially when it becomes endemic; it is destructive to the achievement of the type of society that was envisaged by the foremost nationalists. Thus, corruption is a cancer in any society (Hoffman, 2012). Emphatically, corruption in the public sector is the misuse of public office for private gain which have severe adverse effects on the socioeconomic development of a country through a reduced income, poor health and education status, vulnerability to shocks and other characteristics (as a result of diverted funds) in countries already struggling with the strains of economic growth and democratic transition. All these are viewed as exacerbating conditions of poverty, (Chetwynd, Chetwynd and Spector, 2003). Potentially, corruption affects the lives of poor people through many channels, namely: diverting government spending away from socially valuable goods, such as education; diverting public resources from infrastructure investments that could benefit poor people, such as health clinics; tending to increase public spending on capital intensive investments that offer more opportunities for kickbacks, such as defense contracts; lowering the quality of infrastructure, since kickbacks are more lucrative on equipment purchases; and also by undermining public service delivery (World Bank, 2001). However, corruption, by itself, does not produce poverty. Rather, corruption has direct consequences on economic and governance factors that in turn produce poverty. Thus, the relationship examined by researchers is an indirect one (Chetwynd et al, 2003). 
The contradiction of rising poverty in a rapidly expanding economy has led to the conclusion by policy makers and researchers that corruption leads to poverty or contribute to poverty (Aina, 2014). Corruption has manifested itself in many forms, such as waste and misallocation of public funds by government officials which denies the provision of social services and infrastructures thereby creating poverty. Several instances of corrupt practices have been reported on the radio and media over the years.

The theoretical underpinnings linking poverty to corruption are based on the position that poor people are more likely to be victims of corrupt behaviors by governments officials as the poor often rely heavily on services provided by governments (Chetwynd et al, 2003; Justesen and Bjornskov, 2014).Regardless of the general belief that corruption is the root cause of poverty in the developing nations, there are no empirical evidences or unanimity among researchers to support the claim or hypothesis that corruption is directly responsible for increasing level of poverty in the literature (Chetwynd et. al., 2003; Aina, 2014).

However, in the literature, there seems to be a general consensus about the indirect relationship between poverty and corruption. The consequences of corruption are centered on the economic and governance factors which later result in poverty. According to Ellis (2015), corruption is not a primary cause of poverty, rather corruption fuels poverty through a reduction of the quality and quantity of public services (education, health, housing etc.) which benefit mainly the poor. Therefore, Wickberg (2012) concluded that the influence of corruption on poverty occurs through its impact on income, access to services (economic factors), and resource distribution (governance factor).

Similarly, taking an inverted approach, Rothstein and Holberg (2011) showed that the correlation between poverty levels and control of corruption is relatively weak but it is reinforced by the strong correlation between control of corruption and economic growth (proxied by GDP per capita). This buttressed the point that the relationship between poverty and corruption is indirect through economic growth. Estefania (2010) applied both direct and indirect measures of corruption to show correlations between different poverty measurements and corruption indicators for 18 Latin American countries, and concluded by presenting a significant negative relationship between poverty and corruption levels. In the same way, Gupta, Davoodi and Alonso-Terme (2002) concluded that policies that reduce corruption have a tendency to reduce income inequality which will in turn have a decreasing effect on poverty level. They presented evidence that rising level of corruption increases income inequality and poverty by showing that an increase of one standard deviation in corruption increases the Gini-coefficient of income inequality by about 11 percentage points and income growth of the poor by about 5 percentage points yearly.
On the other hand, in a causal analysis between corruption and poverty, Vahideh, Zakariah and Hesam (2010) investigated the Granger causal relationship between corruption and poverty, using dynamic panel system GMM estimators, and focusing on capability poverty proxied by human poverty index (HPI) with a sample of 97 developing countries for the periods of 1997 to 2006. They concluded that a bidirectional causal relationship exists between corruption and poverty. Using micro level survey data from the Afrobarometer, and multilevel regressions across 18 countries, Justesen and Bjornskov (2014) showed that poor people are much more prone to experience having to pay bribes to government officials. Most importantly, they found that poverty strongly increases the frequency with which individuals face demands for bribes in return for obtaining services from government officials, particularly in urban areas. These findings therefore support the claim that poverty also has a feedback effect on the level of corruption.

\section{RESEARCH METHODOLOGY}

This study may have a comprehensive effort on this topic for the economy of Indonesia and it will contribute to the study of corruption, growth and poverty in several ways: (i) using a comprehensive measure of corruption and poverty; (ii) structural break unit root test; (iii) the ARDL bounds testing approach to cointegration for long run relationship between the variables in the presence of structural breaks; (iv) ECM for short run impacts; and (v) Innovative Accounting Approach (IAA) to test the robustness of the analysis i.e. Variance Decomposition (VD) and Impulse Response Function (IRF). In addition to the focus variables of corruption and poverty, we also include three control variables in model. The control variables are GDP per capita because per capita GDP is highly correlated with poverty, inflation rate and unemployment. The general functional form of the model is given below as follows:

$$
P O V_{t}=f\left(C O R_{t}, G D P_{t} I N F_{t}, U N E_{t}\right)
$$

In this equation, POV is poverty measured by poverty headcount ratio at national poverty lines (\% of population), COR is corruption measured by CPI (Corruption Perception Index) as index denotes the level of corruption where countries with a higher Corruption Perception Index score are perceived as having less corruption, GDP is economic growth measured by GDP per capita growth (annual \%), INF illustrates the inflation rate for consumer prices (annual \%), and UNE is unemployment for youth total (\% of total labor force ages 15-24 based on modeled ILO estimate). We have converted all the series into natural logarithm for consistent and reliable results. The log-linear specification provides better results because the conversion of the series into logarithm 
reduces the sharpness in time series data (Shahbaz, 2012).

Poverty headcount ratio is measured based on national (i.e. country-specific) poverty lines. A country may have a unique national poverty line or separate poverty lines for rural and urban areas, or for different geographic areas to reflect differences in the cost of living or sometimes to reflect differences in diets and consumption baskets. Poverty estimates at national poverty lines are computed from household survey data collected from nationally representative samples of households. National poverty lines are the benchmark for estimating poverty indicators that are consistent with the country's specific economic and social circumstances.

National poverty lines reflect local perceptions of the level and composition of consumption or income needed to be non-poor. Almost all national poverty lines are anchored to the cost of a food bundle - based on the prevailing national diet of the poor - that provides adequate nutrition for good health and normal activity, plus an allowance for nonfood spending. National poverty lines must be adjusted to inflation between survey years to remain constant in real terms and thus allow for meaningful comparisons of poverty over time. Because diets and consumption baskets change over time, countries periodically recalculate the poverty line based on new survey data. In such cases the new poverty lines should be deflated to obtain comparable poverty estimates from earlier years. The data is based on the two most recent years for which survey data are available. Survey year is the year in which the underlying household survey data were collected or, when the data collection period bridged two calendar years, the year in which most of the data were collected. ${ }^{2}$

Over the 1995 to 2011 period, the CPI ranks countries/territories on a scale of 0 to 10 , with 0 indicating highly corrupt (most corrupt) and 10 indicating very clean (least corrupt). In 2012, the Corruption Perception Index scores countries on a scale of 0 to 100 instead of a scale of 0 to 10 . This article uses the CPI, which is provided and accumulated by Transparency International. It is the broadest index available and it is matching intentions of this paper as it interested in the perceived level of corruption in a country. We are not targeting any specific form or measure of corruption. The CPI index currently contains data from 180 countries and has been recorded since 1995 . In order to make interpretation more natural and for the sake of simplicity, This article follows the same procedure as Wei (2000) and Li et al. (2000) by taking 10 minus the Corruption Perception Index. Thus, a higher score now represents a higher level of corruption.

Inflation is another classic variable in the development literature theorized to harm growth. Inflation, regardless of how it is measured, has consistently been shown to harm growth (Levine and
Renelt, 1992). Inflation is especially important in the literature examining the effects of inequality on subsequent growth because inflation increases inequality (Li and Zou, 2002). Thus, this article uses inflation as measured by the annual growth rate of the GDP deflator. This measure shows the rate of price change in the economy as a whole. follows:

The base empirical equation is modeled as

$$
\begin{gathered}
\ln P O V_{t}=\theta_{1}+\theta_{2} \ln C P I_{t}+\theta_{3} \ln G D P_{t}+\theta_{4} \operatorname{lnINF_{t}} \\
+\theta_{5} \ln U N E_{t}+\varepsilon_{i}
\end{gathered}
$$

Table 1. Sources and Characteristics of Sample Data

\begin{tabular}{cccccc}
\hline Variables & $\begin{array}{c}\text { Unit of } \\
\text { Meas. }\end{array}$ & Mean & Std. Dev. & Min. & Max. \\
\hline $\begin{array}{c}\text { Poverty } \\
\text { (POV) }\end{array}$ & $\%$ & 2.695 & 0.228 & 2.360 & 3.150 \\
$\begin{array}{c}\text { Corruptio } \\
\text { n (COR) }\end{array}$ & $0-10$ & 2.000 & 0.090 & 1.840 & 2.120 \\
$\begin{array}{c}\text { Growth } \\
\text { (GDP) }\end{array}$ & $\%$ & 1.386 & 0.251 & 0.790 & 1.880 \\
$\begin{array}{c}\text { Inflation } \\
\text { (INF) }\end{array}$ & $\%$ & 2.063 & 0.622 & 1.260 & 4.070 \\
$\begin{array}{c}\text { Unemplo } \\
\text { yment } \\
\text { (UNE) }\end{array}$ & $\%$ & 2.835 & 0.203 & 2.380 & 3.190 \\
\hline
\end{tabular}

Source : Transparency International and World Bank

We first tested the unit root of all the variables using both the Augmented Dickey-Fuller (ADF) and Phillips-Perron (PP) tests. After checking for the unit root, we can then employ either the Johansen and Juselius (1990) or the Engle Granger cointegration test if the series of each variable is integrated with the same order. If we find that the variables used in this study are not all integrated with the same order and hence, we will employ the ARDL approach to test for cointegration as Johansen method for testing for cointegration requires the variables to be integrated with the same order. Otherwise the predictive power of the models tested would be affected.

The ARDL approach as developed by Pesaran and Shin (1999) and Pesaran et al. (2001) overcome these problems as ARDL can be applied irrespective of whether the variables are I(0) and/or I(1). More importantly, Johansen approach is not suitable for studying cointegration for small sample time series as in our study. ARDL on the other hand provides robust results even in small samples (Pesaran and Shin, 1999) and this is advantageous as income inequality data is only available for annual data and the period available are also limited for many emerging economies like Indonesia. Another benefit of ARDL is that it allows the optimal lag lengths for the variables to differ, while the Johansen approach requires that all variables in the model to have the same number of lags. For this study, AIC (Akaike Information Criterion) has been used to determine the optimal lag lengths for the ARDL model.

Even though using Schwarz Bayesian Criterion (SBC) provides smaller standard errors for some of our models tested under the ARDL, we find that in some

${ }^{2}$ (https://www.indexmundi.com/facts/indicators/SI.POV.NAHC). 
models, SBC runs the models with ARDL $(0,0,0,0)$ such that no ECM statistical output was produced. This is due to the SBC's method of choosing the minimum lag possible and accordingly, we find that AIC is more suitable for our study.

The first step in ARDL is to empirically investigate the existence of long run relationship between the variables. The calculated F-statistic is then compared to the upper and lower critical bound provided by Pesaran et al. (2001) which correspond to the assumptions that the variables are I(0) and I(1) respectively. If the calculated F-statistics exceeds the upper critical bound (UCB), then the series are cointegrated; if it is below the lower critical bound (LCB), there is no cointegration. If the calculated Fstatistics is between the UCB and the LCB, then decision on cointegration is inconclusive and knowledge of the cointegration rank of the forcing variables is required to continue further.

The critical values of the F-statistic for different number of variables $(\mathrm{k})$, and whether the ARDL model contains an intercept and/or trend are available in and Pesaran et al. (2001). They give two sets of critical values. The calculated F-statistic is then compared to the upper and lower critical bound provided by Pesaran et al. (2001) which correspond to the assumptions that the variables are I(0) and I(1) respectively. If the calculated F-statistics exceeds the upper critical bound (UCB), then the series are cointegrated; if it is below the lower critical bound (LCB), there is no cointegration. If the calculated Fstatistics is between the UCB and the LCB, then decision on cointegration is inconclusive and knowledge of the cointegration rank of the forcing variables is required to continue further. For each application, there is a band covering all the possible classifications of the variables into I(0) and I(1).

The ARDL cointegration test is testing the following hypotheses:

$\mathbf{H}_{\mathbf{0}}: \delta 1=\delta 2=\delta 3=\delta 4=0$ i.e there is no long run relationship between the variables,

$\mathbf{H}_{\mathbf{a}}: \delta 1 \neq \delta 2 \neq \delta 3 \neq \delta 4 \neq 0$ i.e there is cointegration or long run relationship between the variables.

In the second step, once cointegration between the variables has been established, the long run coefficients and the error correction term (ECT) can be estimated. The ARDL cointegration procedure allows cointegrating relationship to be estimated by OLS once the lag order is selected. The model can be specified as follows :

$$
\begin{gathered}
\Delta P O V=a_{0}+\sum_{i=1}^{k} b_{i} \Delta C O R_{t-1}+\sum_{i=1}^{k} c_{i} \Delta G D P_{t-1}+ \\
\sum_{i=1}^{k} d_{i} \Delta I N F_{t-1}+\sum_{i=1}^{k} e_{i} \Delta U N E_{t-1}+\delta_{1} L C O R_{t-1}+ \\
\delta_{2} L G D P_{t-1}+\delta_{3} L_{I N F_{t-1}}+\delta_{4} L U N E_{t-1}+\mu_{t}
\end{gathered}
$$

where POV is for poverty, COR is corruption, and GDP is GDP per capita growth, INF is inflation and UNe is unemployment. $\Delta$ denotes the first difference of the logged variables and $u_{t}$ is the residual term. This equation is a standard VAR model in which $a$ linear combination of lagged-level variables are added as proxy for lagged error terms. The coefficients $b_{i}, c_{i}, d_{i}$ and $e_{i}$ represent the short run effects while all $\delta_{j}$ (for $\mathrm{j}=1 \ldots 4$ ) represents the long run effects.

The dynamic error correction model (ECM) is derived from the ARDL model through a simple linear transformation where the ECM integrates the short run dynamics with long run equilibrium, without losing the long run information. The causality in the earlier step will be tested and confirmed through the t-statistic of the ECM while the coefficient of the ECT from the ECM indicates the speed of adjustment of the dependent variable towards its long run equilibrium. The endogeneity or exogeneity of the variable is tested though the ECM, and the same equation is used with each proxy of corruption as well as poverty in turn being the dependent variable. The ECM tests the following hypothesis:

\section{$\mathrm{H}_{0}$ : The variable is Exogeneous,}

$\mathrm{H}_{\mathrm{a}}$ : The variable is Endogenous.

For the purposes of determining the relative degree of endogeneity or exogeneity of the variables, we applied the generalized Variance Decomposition (VD) technique. The VDC provides a decomposition of the variance of the forecast errors of the variables in the Vector Auto Regression (VAR) at different periods. The relative exogeneity or endogeneity of a variable can be determined by the proportion of the variance explained by its own past. The variable that is explained mostly by its own past is deemed to be the most exogenous of all.

Finally, as noted early, well-targeted social programs are believed to transfer relatively more income to the poor and reduce the incidence of poverty. In reality, it is quite conceivable that much of the benefits of social programs accrue to the middle- and higher-income groups. To assess the impact of social spending on the income growth of the poor, two broad proxies for social spending are included, all in relation to GDP; these are government spending (expenditure) on (1) education ( $\%$ of GDP) and (2) health (\% of GDP).

Beside that, it was argued previously that corruption could perpetuate poverty by reducing growth. To test this argument, the real per capita GDP growth rate will also be correlated with corruption. Therefore the results will determine whether corruption reduces the overall growth rate of the economy and whether corruption leads to higher poverty by reducing economic growth.

At the outset, each of the variables representing social spending of government and growth will be correlated on corruption by simple Pearson Product Moment Coefficient of Correlation estimation ${ }^{3}$ on corruption index. The discussion here underscores that how corruption can affect poverty through social spending and growth. To determine whether the data support this indirect channel, social spending and

${ }^{3}$ Estimated with IBM SPSS Statistics Version 22 
growth will be correlated individually on a corruption index as following formula :

$$
r=\frac{n \sum_{i=1}^{n} X_{i} Y_{i}-\sum_{i=1}^{n} X_{i} \sum_{i=1}^{n} Y_{i}}{\sqrt{n \sum_{i=1}^{n} X_{i}^{2}-\left(\sum_{i=1}^{n} X_{i}\right)^{2} \cdot \sqrt{n \sum_{i=1}^{n} Y_{i}^{2}-\left(\sum_{i=1}^{n} Y_{i}\right)^{2}}}}
$$

where :

$\begin{array}{lll}\mathrm{r} & : & \text { pearson correlation } \\ \mathrm{X} & : & \text { corruption index } \\ \mathrm{Y} & : & \text { social spending and growth } \\ \mathrm{n} & : & \text { amount of sample }\end{array}$

\section{RESULTS AND FINDINGS}

The unit root test provides guidance to ascertain whether ARDL is applicable or not because it is only applicable to the analysis of variables that are integrated of order zero [I(0)] or order one [I(1)], but not applicable when higher order of integration such as I(2) variable is involved. Testing the stationarity of the variables is important to avoid spurious regression. Thus, the Augmented Dickey-Fuller (ADF) of Dickey and Fuller (1981) and Phillips-Perron (PP) test by Phillips and Perron (1988) technique were used to investigate the stationarity of the variables. The ADF and PP test results are shown in Table 2.

Table 2. Results of the ADF and PP test

\begin{tabular}{|c|c|c|c|c|}
\hline \multicolumn{5}{|c|}{ Level } \\
\hline & \multicolumn{2}{|c|}{ ADF Test } & \multicolumn{2}{|c|}{ PP Test } \\
\hline Variables & $\begin{array}{c}\mathrm{t}- \\
\text { statistic }\end{array}$ & Prob.* & $\begin{array}{c}\mathrm{t}- \\
\text { statistic }\end{array}$ & Prob.* \\
\hline POV & -3.250 & $0.002^{*}$ & -3.531 & $0.001^{*}$ \\
\hline COR & -1.546 & 0.112 & -1.707 & $0.082^{* * *}$ \\
\hline GDP & -1.010 & 0.268 & -1.034 & 0.259 \\
\hline INF & -0.539 & 0.469 & -0.884 & 0.321 \\
\hline UNE & 0.681 & 0.855 & 0.504 & 0.816 \\
\hline \multicolumn{5}{|c|}{$1^{\text {st }}$ Difference } \\
\hline POV & -4.297 & $0.000^{*}$ & -4.262 & $0.000 *$ \\
\hline COR & -4.373 & $0.000 *$ & -4.293 & $0.000 *$ \\
\hline GDP & -4.361 & $0.000^{*}$ & -4.361 & $0.000^{*}$ \\
\hline INF & -6.806 & $0.000^{*}$ & -9.346 & $0.000^{*}$ \\
\hline UNE & -3.293 & $0.002^{*}$ & -3.293 & $0.002^{*}$ \\
\hline
\end{tabular}

The null hypothesis of the unit root problem is rejected at the first difference. This shows that most variables are found to be stationary at $1^{\text {st }}$ difference implying that variables are integrated at I(1), and the variables used in this study are not all integrated of the same order, hence we may employ the ARDL approach to test for cointegration.

Having confirmed the stationarity of the variables, the next step of the analysis was to test for cointegration among the variables. Therefore, ARDL bounds testing approach is employed to test for the existence of long run relationship. However, in order to do this, it is important to identify an appropriate lag length to calculate the F-statistics. The ARDL model is sensitive to the lag order. In addition, optimum lag order would be helpful in reliable and consistent result from the analysis. Thus, the Akaike Information Criterion (AIC) is considered to obtain the optimum lag length. The choice of this criterion is based on the stricter penalties imposed by AIC. This AIC provides better and consistent results compared to other lag length criteria (Uddin, Shahbaz, Arouri, and Teulon, 2013). Based on the lag selection criteria test (shown in Figure 2), the AIC maximum lag length of 1 was selected and employed in the estimation of ARDL model $(1,0,1,1,1)$.

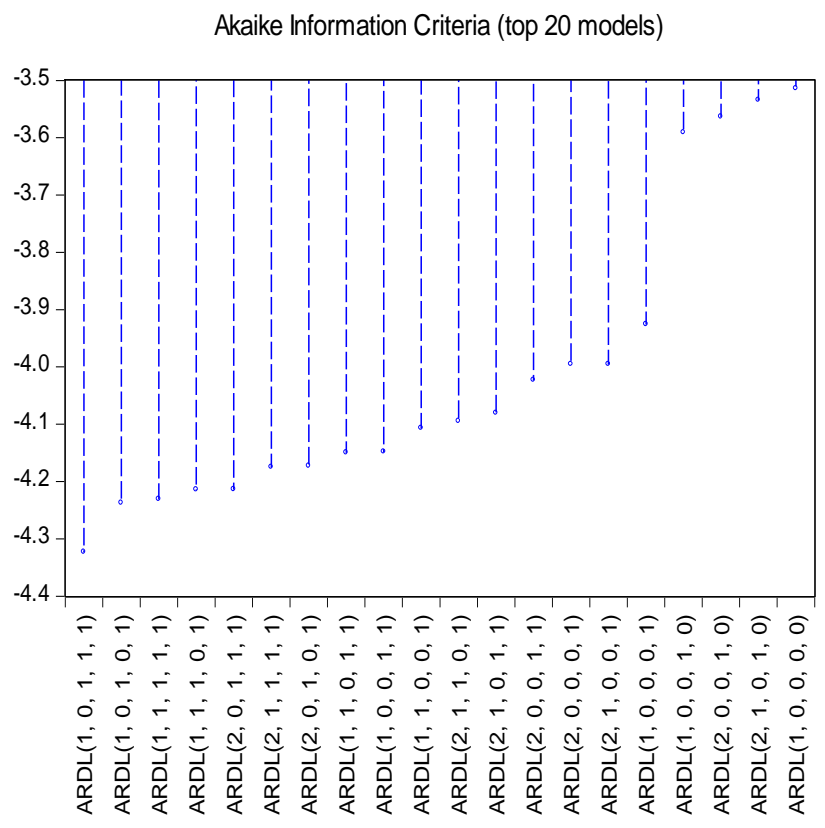

Figure 2. Lag Order Selection Criteria Based on AIC

After stationary tests among variables and choosing the lap optimum for model, then the variables were tested for cointegration by applying ARDL bound testing approach for testing the Null that there is no long-run (LR) relationship among the variables.

The computed F-statistic is compared with upper and lower critical bounds generated by Pesaran et al. (2001) to test for the existence of cointegration. The null hypothesis is $\mathrm{H}_{0}: \lambda_{\mathrm{j}}=0$, (where $\mathrm{j}=1,2, \ldots, 5$ ) in equation (4). This implies no long run relationship among the variables, against the alternative hypothesis, $\mathrm{H}_{1}: \lambda_{\mathrm{j}} \neq 0$, implying the existence of long run relationship among the variables. The results in Table 3 showed that the computed F-statistic (4.100) is greater than the upper bound (4.01) at 5\% level of significance with unrestricted intercept and no trend (Upper bound is 4.01 and Lower bound is 2.86). This implies that there is evidence to reject the null hypothesis of no long run relationship among the variables. Hence, the alternative hypothesis is accepted that there is long run equilibrium relationship among poverty, corruption, GDP, inflation rate, and unemployment. 
Table 3. Result of Bounds Testing

\begin{tabular}{ccc}
\hline $\begin{array}{c}\text { Estimation } \\
\text { Model }\end{array}$ & $P O V=f(C O R, G D P, I N F, U N E)$ \\
\hline Test Statistic & Value & $\mathrm{k}$ \\
F-statistic & $4.100^{* *}$ & 4 \\
\hline \multicolumn{3}{c}{ Critical Value Bounds } \\
\hline Significance & Lower Bound & Upper Bound \\
\hline $10 \%$ & 2.45 & 3.52 \\
$5 \%$ & 2.86 & 4.01 \\
$1 \%$ & 3.74 & 5.06 \\
\hline Decision & \multicolumn{3}{c}{ Reject the Null Hypothesis } \\
\hline \multicolumn{3}{c}{ ** Significance at 5 \% level }
\end{tabular}

The Error Correction Model (ECM) associated with ARDL was estimated to show the short and long run effect of corruption on the income inequality level. In addition to the fact that ECM comprises the short run transitory effects and the long run relationships, the speed of adjustment of the dependent variable to changes in the independent variables is also determined within the framework.

Tabel 4. Results of the Error Correction Model (ECM) for Short Run

\begin{tabular}{ccccc}
\hline Variable & Coefficient & Std. Error & t-Statistic & Prob. \\
\hline D(POV(-1)) & 0.1431 & 0.2460 & 0.5818 & 0.5919 \\
D(COR) & 0.4650 & 0.8990 & 0.5173 & 0.6322 \\
D(GDP) & 0.0068 & 0.1111 & 0.0613 & 0.9540 \\
D(GDP(-1)) & -0.0233 & 0.0498 & -0.4674 & 0.6645 \\
D(INF) & 0.0507 & 0.0262 & 1.9323 & 0.1255 \\
D(INF(-1)) & 0.0764 & 0.0339 & 2.2521 & $0.0874 * * *$ \\
D(UNE) & 0.0359 & 0.1035 & 0.3465 & 0.7464 \\
D(UNE(-1)) & 0.1716 & 0.1667 & 1.0292 & 0.3615 \\
ECT(-1) & -1.6007 & 0.5678 & -2.8189 & $0.0479 * *$ \\
C & -0.0159 & 0.0194 & -0.8220 & 0.4572 \\
\hline
\end{tabular}

** Significance at $5 \%$ level, ${ }^{* * *}$ Significance at $10 \%$ level

The results of the ECM in Table 4 showed the short effect of corruption on poverty level. From the p-value (Prob.) of error correction (ECM(-1)) in that table, we can conclude that in the short-run both poverty and corruption are endogenous. That is all these variables are dependent on other variables, which helps us to argue that there is dynamic relationship among poverty, corruption, growth, inflation and unemployment in short-run. The lagged ECM terms for model have the expected negative sign.

In the short run, the results show that only inflation variable is significant in $10 \%$ significance level $(\mathrm{p}<0.08, \mathrm{t}=2.252)$ and it has a positive effect on the level of poverty headcount ratio in Indonesia. A 1\% change in inflation rate, other things being equal, will change the level of poverty by $0.07 \%$ in the same direction. Inflation, as one of the aspects of macroeconomic instability, is a regressive tax, which its burden is especially carried by those in lower income groups since the poor tend to hold most of their wealth in the form of cash, and also they are commonly less able than the rich to secure the real value of their incomes and wealth from inflation (Negin et al., 2010). Therefore, price increases generally erode the real wages and assets of the poor more than those that belong to the rich.

In the long run of Table 5, corruption have significant effect on the level of poverty ratio in $1 \%$ significance level. This implies that in the long run, there is relationship between corruption and poverty. Corruption affects inequality in an inverted U-shaped way where poverty in countries with an intermediate level of corruption is higher than that in countries with little or rampant corruption. In the long run, the coefficient of corruption effect implies that $1 \%$ increase in corruption index would increase the poverty ratio by $1.36 \%$.

Table 5. Results of ARDL Estimation Based on AIC for Long Run

\begin{tabular}{ccccc}
\hline \multicolumn{5}{c}{ Long Run Coefficients } \\
\hline Variable & Coefficient & Std. Error & t-Statistic & Prob. \\
\hline LnCOR & 1.361451 & 0.195674 & 6.957753 & $0.0002^{*}$ \\
LnGDP & -0.226594 & 0.061606 & -3.678127 & $0.0079^{*}$ \\
LnINF & 0.089363 & 0.044940 & 1.988475 & $0.0871^{* * *}$ \\
LnUNE & 0.386421 & 0.101084 & 3.822787 & $0.0065^{*}$ \\
Constant & -1.040569 & 0.263975 & -3.941917 & $0.0056^{*}$ \\
\hline
\end{tabular}

* Significance at $1 \%$ level, ${ }^{* * *}$ Significance at $10 \%$ level

Figure 3 demonstrates the relationship between corruption and poverty. The figure is based on the regression in Table 5. A higher growth in the corruption index means the country has a higher growth rate of corruption.

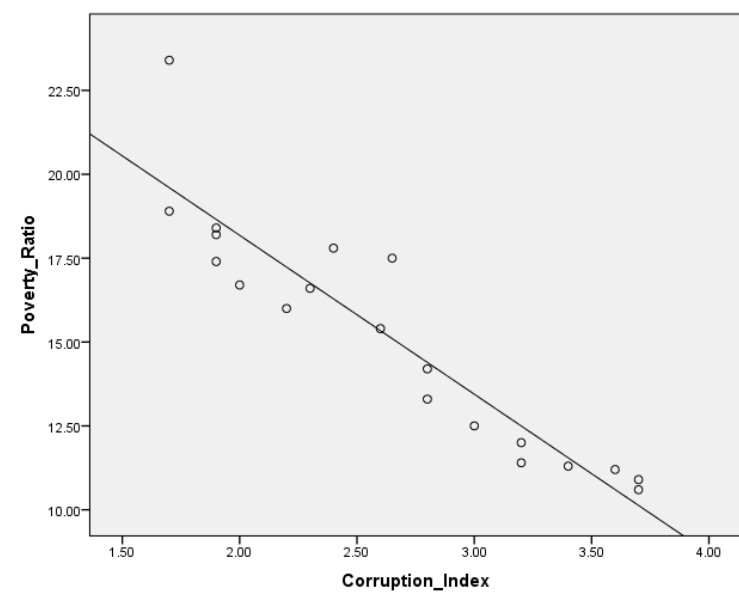

Figure 3. Scatter Plot of Relationship between Corruption Index and Poverty Index

The regressions of ARDL above have shown that corruption among others affect poverty. This could be labeled as the direct impact of corruption on poverty. However corruption may also affect poverty indirectly through its impact on variables such as social spending on education and health. To determine whether data supports the role of social spending in alleviating poverty and how corruption can affect these variables 
through social spending, social spending is regressed on a constant and a corruption index.

Table 6. Results of Pearson Correlation

\begin{tabular}{|c|c|c|c|}
\hline \multicolumn{4}{|c|}{ Correlations } \\
\hline & & $\mathrm{CPI}$ & EDU \\
\hline \multirow[t]{4}{*}{ CPI } & $\begin{array}{l}\text { Pearson } \\
\text { Correlation }\end{array}$ & 1 & $-.479 * * *$ \\
\hline & Sig. (2-tailed) & & .052 \\
\hline & Covariance & .006 & -.031 \\
\hline & $\mathrm{N}$ & 21 & 17 \\
\hline \multirow[t]{4}{*}{ EDU } & $\begin{array}{l}\text { Pearson } \\
\text { Correlation }\end{array}$ & -.479 & 1 \\
\hline & Sig. (2-tailed) & $.052^{* * *}$ & \\
\hline & Covariance & -.031 & .733 \\
\hline & $\mathrm{N}$ & 17 & 17 \\
\hline \multicolumn{4}{|c|}{ Correlations } \\
\hline & & CPI & HEALTH \\
\hline \multirow[t]{4}{*}{ CPI } & $\begin{array}{l}\text { Pearson } \\
\text { Correlation }\end{array}$ & 1 & $-.918^{*}$ \\
\hline & Sig. (2-tailed) & & .000 \\
\hline & Covariance & .007 & -.015 \\
\hline & $\mathrm{N}$ & 16 & 16 \\
\hline \multirow[t]{4}{*}{ HEALTH } & $\begin{array}{l}\text { Pearson } \\
\text { Correlation }\end{array}$ & $-.918^{* *}$ & 1 \\
\hline & Sig. (2-tailed) & .000 & \\
\hline & Covariance & -.015 & .041 \\
\hline & $\mathrm{N}$ & 16 & 16 \\
\hline \multicolumn{4}{|c|}{ Correlations } \\
\hline & & CPI & GROWTH \\
\hline \multirow[t]{4}{*}{ CPI } & $\begin{array}{l}\text { Pearson } \\
\text { Correlation }\end{array}$ & 1 & $-.953^{*}$ \\
\hline & Sig. (2-tailed) & & .000 \\
\hline & Covariance & .008 & -49.463 \\
\hline & $\mathrm{N}$ & 23 & 22 \\
\hline \multirow[t]{4}{*}{ GROWTH } & $\begin{array}{l}\text { Pearson } \\
\text { Correlation }\end{array}$ & $-.953^{* *}$ & 1 \\
\hline & Sig. (2-tailed) & .000 & \\
\hline & Covariance & -49.463 & $\begin{array}{r}371762.43 \\
6\end{array}$ \\
\hline & $\mathrm{N}$ & 22 & 22 \\
\hline
\end{tabular}

The results are shown in Table 6 for two measures of social spending. The results show that higher corruption tends to have lower levels of social spending. of the two simple correlations, both are statistically significant at 10 percent level for education spending and at the 1 percent level for education. Corruption is statistically significant at the 10 percent level in the negative sign on education spending of government and at the 1 percent level in negative sign on health spending of government. A 1\% change in corruption index, other things being equal, will change the level of education spending by $0.47 \%$ and level of health spending by $0.91 \%$ in the opposite direction. This implies that increasing corruption will decrease the total spending of government for education and health. Whereas the previous section stated that higher social spending increases the income growth of the poor. Together these results show that corruption not only reduces income growth of the poor directly, but also indirectly through lower social spending for education and health. The data are consistent, therefore, with the view that corruption reduces social spending. The results in Table 6 also indicate that show that corruption reduces the overall growth rate of the economy. Together, these results indicate that corruption leads to higher poverty by reducing economic growth.

From Table 5, we also know that the coefficient of growth in significance effect implies that 1\% increase in GDP per capita growth would decrease the poverty ratio by $0.22 \%$ in long run. This is in line with the a priori expectation of negative relationship between growth and income inequality where an increase in economic growth is expected to reduce income inequality. The negative significant relationship between poverty economic growth and poverty ratio in Indonesia is worthy of concern. This serves as evidence that growth in the economic activities, aggregate incomes or outputs has trickled down to the bottom poor people. This implies that, larger part of the economy resources are in the hand of the few rich called the capitalist. On other view, this also implies that the structural shift in the processes of economic growth in Indonesia does follow the common assumption in the economic theory which says that when an economic growth process generates movement of labor from low productivity agriculture to the high productivity industrial sector this will improve the income and welfare of the labor force and caused a client in the inequality of income.

The coefficient of unemployment variable also show a positive significance effect on poverty in the long run. This coefficient implies that $1 \%$ increase in unemployment ratio would increase the poverty ratio by $0.38 \%$. This is in line with the research by Sharp et. al. (1997) identified the causes of poverty as; the low quality of the labor force in most developing countries; inadequate amounts of available capital resources which translates directly into low labor productivity and poverty; failure or inability to adapt to modem production techniques. In many poor countries, the resources are either not fully or efficiently used and lastly, high rates of population growth, which exceed the rate of economic growth, tend to complicate the problem of scarcity.

Similarly, the inflation rate has a positive significance effect on poverty by $0.08 \%$. This is confirmed the explanation by Jhingan (2001) said that principal causes of poverty in India to include the following: (1) the rise in unemployment has increased the levels of poverty; and (2) high rate of inflation, low levels of technology, capital efficiency and the social factors that are prevalent in India.

Moreover, the coefficient of the Error Correction Term (ECT $\left.\mathrm{t}_{\mathrm{t}-1}\right)$ in Table 4 is the speed of adjustment of poverty level to shocks in exogenous variables in the model. The negative and statistically significant of the coefficient of the Error Correction Term (ECT) 
indicates a stable process of adjustment to the long run equilibrium.

The relative exogeneity or endogeneity of a variable can be determined by the proportion of the variance explained by its own past. The variable that is explained mostly by its own shocks (and not by others) is deemed to be the most exogenous of all. We started out applying generalized VDCs and obtained the following results.

Tables 7 above showing the results of VDCs for model. Those percentages highlighted in grey indicate the contribution of the variable's own shock towards explaining the forecast error variance of each variable. From the VDCs, we can see that in the 1 year horizon period, poverty is the most exogenous and growth is the most endogenous followed by corruption. In the 5 year horizon period, poverty is the most exogenous and growth is the most endogenous again by poverty. In the medium to long run, growth becomes more endogenous followed by poverty and corruption.

Table 7. Result of Variance Decomposition

\begin{tabular}{|c|c|c|c|c|c|c|}
\hline $\begin{array}{l}\text { VDCs } \\
\text { of : }\end{array}$ & Per & POV & COR & GDP & INF & UNE \\
\hline POV & 1 & 100.00 & 0.0000 & 0.0000 & 0.0000 & 0.0000 \\
\hline COR & 1 & 0.3096 & 99.690 & 0.0000 & 0.0000 & 0.0000 \\
\hline GDP & 1 & 31.289 & 36.193 & 32.517 & 0.0000 & 0.0000 \\
\hline INF & 1 & 29.562 & 3.2842 & 11.111 & 56.041 & 0.0000 \\
\hline UNE & 1 & 1.3541 & 3.8549 & 0.6469 & 11.573 & 82.570 \\
\hline POV & 5 & 60.454 & 22.621 & 3.2298 & 6.2103 & 7.4837 \\
\hline COR & 5 & 49.3 & 45.2 & 2.83 & 0.5 & 2.0682 \\
\hline GDP & 5 & 28.390 & 24.381 & 21.00 & 3.8873 & 22.338 \\
\hline INF & 5 & & 12.6 & 9.25 & 42. & 5.2072 \\
\hline UNE & 5 & 4.5204 & 18.201 & 0.9639 & 16.461 & 59.852 \\
\hline POV & 10 & 65.587 & 21.4 & 3.49 & 2.95 & 6.5550 \\
\hline COR & 10 & 60.540 & 31.9 & 3.38 & & 3.8197 \\
\hline GDP & 10 & 28.424 & 24.377 & 20.943 & 3.9192 & 22.335 \\
\hline INF & 10 & 33.800 & 13.139 & 8.8228 & $\begin{array}{c}39.108 \\
1\end{array}$ & 5.1280 \\
\hline UNE & 10 & 19.702 & 18.223 & 1.5494 & 12.772 & 47.752 \\
\hline POV & 20 & 67. & & 3.6 & & 5.6980 \\
\hline COR & 20 & 66.035 & 25.426 & 3.6543 & 0.2880 & 4.5957 \\
\hline GDP & 20 & 28.610 & 24.359 & $\begin{array}{c}20.867 \\
6\end{array}$ & 3.9029 & 22.259 \\
\hline INF & 20 & 40266 & 14.579 & 7.9223 & 32.101 & 5.1294 \\
\hline UNE & 20 & 38.214 & 19.333 & 2.3966 & 8.1225 & 31.932 \\
\hline
\end{tabular}

The results suggest that the contribution of corruption in poverty is $21.28 \%$ and growth explains poverty only by $3.69 \%$ in 20 years period. A $67.97 \%$ portion of poverty is explained by own innovative shocks (or other factors could not be captured in the model). The shocks stemming in poverty contribute in corruption index by $21.28 \%$. The contribution of economic growth in corruption index is $24.35 \%$. Corruption and poverty explain economic growth by approximately per each $3.6 \%$ respectively. Interestingly, in the 20 years period, the innovative shock stems in growth explains itself only by $20.86 \%$. Overall our results indicate that corruption can lead the poverty. Corruption Granger causes the poverty but relation is weak relatively.

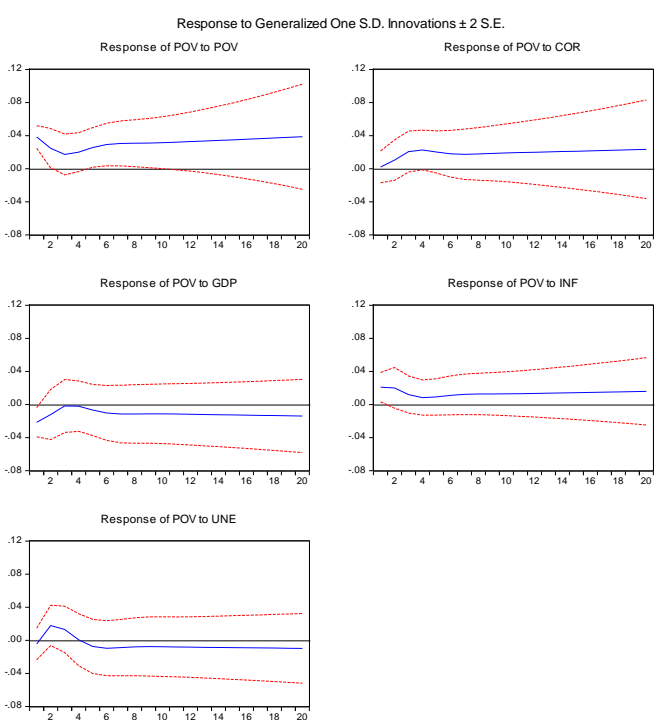

Figure 4. Result of Impulse Response

We also applied the generalized impulse response functions (IRF) to look at the impact on shock of one variable on the other variables and their degree of response. The IRF essentially produces the same information as the VDC, except that they are presented in graphical form. The impulse response function is alternative of variance decomposition method shows how long and to what extent dependent variable reacts to shock stemming in independent variables. The results from Figure 4 above indicate that the response in poverty due to forecast error stemming in corruption indexes initially increasing since $1^{\text {th }}$ to $4^{\text {th }}$ period then decreasing till $8^{\text {th }}$ and goes upwards until end period. The response of poverty is negative due to forecast error in growth. Economic growth reduces poverty till end time horizons. Unemployment shows mixed impact of poverty where till $2^{\text {th }}$ time horizon poverty starts to increase then decrease after $3^{\text {th }}$ time horizons.

\section{CONCLUSIONS}

The results from the above analysis indicated that corruption affects poverty level especially in the long run. Corruption has an effect on poverty because corrupt activities have the effect of depriving the poor of the finances and resources that could have been used to improve their lives through the provision of poor health and education facilities, poor infrastructures, vulnerability to shocks and other poverty characteristics (as a result of diverted funds) in Indonesia. This is in line with the postulations of Vahideh, Zakariah and Hesam (2010) and Rothstein and Holberg (2011). Thus, the impact of corruption on poverty is considerable that $1 \%$ increase in corruption index would increase the poverty ratio by $1.36 \%$.

The negative implication of corruption on the life of the citizens is a major disaster in the economy and harmful to the growth and development of the citizens in particular and the economy in general. For effective sustainable and management of this disaster, government should embark on policies that will reduce 
the level of corruption significantly so as to have positive influence on the standard of living of the citizens in terms of quality and efficient education, sound management of our natural resources, provision of good health facilities and other infrastructures that will transcend to the growth of the economy.

Also, the leading Indonesia's Corruption Eradication Commission (Komisi Pemberantasan Korupsi), abbreviated as KPK, as a government agency established to fight corruption, and all institutions related need to join hands with the fast growing economies to stop the corrupt officials from getting away with it by imposing reasonable sanctions that will serve as a deterrent to others. This may be informing of arresting and conviction of several individuals that are found guilty of the offence. Furthermore, the G20 needs to prove its global leadership role and prevent money laundering into their country. This can be done by signing international pacts with the nations and return the billions of stolen assets to the affected countries. There should be adequate funding of anti-poverty agencies and programs and the agencies should be properly monitored in order to carry out the necessary programs that are meant for the poor. Finally, anticorruption efforts need to be strengthened and sustained. This will help in eradicating high level of poverty among the people.

The empirical evidence presented in this paper also shows that corruption has significant distributional consequences by affecting government expenditures. High and rising corruption increases poverty by reducing the level and effectiveness of growth and social spending (education and health).

All ARDL estimation results and pearson correlation findings suggest that the adverse distributional consequences of corruption can be mitigated by: (1) broad based labor intensive growth; (2) efficient spending on education and health; (3) effective targeting of social programs; and (4) a low level of inequality in the access to education.

This study has contributed to knowledge by empirically investigating the impact of corruption on poverty in Indonesia where it was found that high level of corruption has led to an increase in the level of poverty in Indonesia. The study therefore also suggested that for national sustainable development and disaster management (corruption and poverty), the KPK and the other ministries linked should join hands together with the fast growing economies to stop the corrupt officials from getting away with their corrupt practices.

We believe that with a larger sample size the evidence becomes more reliable and the probability of any error will decrease. Our contribution has been towards the patterns that one can project from our regressions. Valuable information and conclusions can be drawn from both the regression model with and without dummies. Additionally regressions on each legal origin group have been composed to show significant results on each one of the groups. Suggestions for further research that could be of use and give even better results is to continue using new and greater datasets as they become available. The difficulties with measuring and defining corruption will sustain however without trying to change either the method of measuring or the definition one can compare newer research with previous for a greater understanding. We only reach a dataset of annually based, hopefully more data will become more accessible and a greater data sets can be constructed. As greater dataset is conducted accurately one can start looking at cross regional regressions for each region depending upon legal origin and possibly achieve greater significance in each group of countries.

\section{REFERENCES}

Aina, 0. (2014). How Corruption Contributes to Poverty. A paper presented at the International Conference on Development of Social Enterprise and Social Business for Eradication of Extreme Poverty and Street Begging at Chittagong, Bangladesh, December 19 -20, 2014.

Alesina, Alberto, and Dani R, (1994). "Distributive Politics and Economic Growth," Quarterly Journal of Economics, Vol. 109, pp. 465 - 90.

Chetwynd, E., Chetwynd, F. and Spector, B. (2003): Corruption and Poverty: A review of Recent Literature. Management Systems International, 600 Water Street, SW Washington, DC 20024 USA.

Chong, A. and Calderon, C. (2000a). "Institutional Quality and Income Distribution," Economic Development and Cultural Change 48: 761-786.

Chong, A. and Calderon, C. (2000b). "Institutional Quality and Poverty Measures in a Cross-Section of Countries," Economics of Governance 1: 123135.

Dabla-Norris, E., and Wade, P. (2002). Production, Rent Seeking and Wealth Distribution. Washington, D.C.: International Monetary Fund.

Deininger, Klaus, and Lyn Squire. (1998). New Ways of Looking at Old Issues: Inequality and Growth. Journal of Development Economics 57, 259-87.

Dickey, D.A., \& Fuller, W. A. (1981). Likelihood ratio statistics for autoregressive time series with a unit root. Econometrica, 49, 1057-1072.

Dincer, C., and Gunalp, B. (2008). Corruption, Income Inequality, and Poverty in the United States. Working Papers No. 54, Fondazione Eni Enrico Mattei

Easterly, William, and Ross Levine, (1997), Africa's Growth Tragedy: Policies and Ethnic Divisions. Quarterly Journal of Economics 111, 1203-1250

Ellis J. (2015). Globalization, Corruption and Poverty Reduction. Transparency International Australia (NSW).

Estefania, C. A.(2010). Poverty and Corruption in Latin America: Challenges for a sustainable development strategy. Revista Opera-Universidad Externado de Colombia 
Gupta, S., Davoodi, H. and Alonso-Terme, R. (2002) "Does Corruption Affect Income Inequality and Poverty?" Economics of Governance 3: 23-45.

Gupta, S., Davoodi, H., and Alonso Terme, R. (1998). Does Corruption Affect Income Equality and Poverty?. IMF Working Paper 98/76.

Hoffman (2012). "Strategies to overcome Poverty and Inequality". A paper presented at "Towards Carnegie III", a conference held at the University of Cape Town from 3 to7 September, 2012.

Jhingan, M.L. (2001). "The Economics of Development and Planning, 34th Edition, Vrinda Publications (P) Ltd, p 737-744.

Johansen, S. and Juselius, K. (1990). "Maximum likelihood estimation and inference on cointegration, with applications to the demand for money", Oxford Bulletin Economics Statistics, 52(2), 169-210.

Johnson, S., D. Kaufman, and A. Shleifer. (1997). The Unofficial Economy in Transition. Brookings Papers on Economic Activity 2, 159-239.

Johnston, M. (1989). "Corruption, Inequality, and Change," in P. M. Ward (Ed.), Corruption, Development and Inequality, London: Routledge: 13-37.

Justesen, M. K. and Bjornskov, C. (2014). Exploiting the Poor: Bureaucratic Corruption and Poverty in Africa. World Development Vol. 58, pp. 106-115

Kaufman, D., and S. Wei, 1998, Does 'Grease Money' Speed Up the Wheels of Commerce? Mimeo, The World Bank.

Keefer, P. (2004). A Review of the Political Economy of Governance: From Property Rights to Voice'. Paper prepared for project on 'The Consequences of Political Institutions in Democracy'. World Bank Research Working Paper (3315). Online at http://info.worldbank.org/etools/BSPAN/Prese ntationView.asp?PID=1967\&EID=907.

Keefer, P. and Knack, S. (1997) "Why Don't Poor Countries Catch Up? A Cross-National Test of An Institutional Explanation," Economic Inquiry 35: 590-602.

Knack, S., and P. Keefer, (1995), Institutions and Economic Performance: Cross-Country Tests Using Alternative Institutional Measures. Economics and Politics 3, 207-27.

Knack, Stephen, and Philip K. (1996). "Institutions and Economic Performance: Cross-Country Tests Using Alternative Institutional Measures," in Economic and Politics, Vol. 7 (November), No. 3. pp. 207 - 27.

Krueger, A.O. (1974). The Political Economy of the Rent-Seeking Society. American Economic Review 64:291-303.

Laban, Raul, and Federico Sturzenegger. (1994). "Distributional Conflict, Financial Adaptation, And Delayed Stabilizations". Economic and Politics, Vol. 6 (November), pp. 257 - 76.

Levine, R., \& Renelt, D. (1992). A sensitivity analysis of cross-country growth regressions. The American Economic Review, 82(4), 942-963.
Li, H., \& Zou, H. (2002). Inflation, growth, and income distribution: A cross-country study. Annals of Economics and Finance, 3, 85-101.

Li, H., Xu, L.C. and Zou, H. F. (2000) "Corruption, Income Distribution, and Growth," Economics and Politics 12: 155-182.

Mauro, P. (1995). "Corruption and Growth," Quartely Journal of Economics, Vol. 110 (August), No. 3, pp. $681-712$

Mauro, P. (1997). The effects of corruption on growth, investment, and government expenditure: A cross-country analysis. Corruption and the global economy, 83. Online at http://www.iie.com

Mo, Pak Hung. (2001). Corruption and Economic growth. Journal of comparative economics; 29; 66-79. Doi:10.1006/jcec.2000.1703. Online at http://www.idealibrary.com

Murphy, Kevin, A. Shleifer, and R. Vishney,. (1991). The Allocation of Talent: Implication for Growth. Quarterly Journal of Economics 105, 503-30.

Ndikumana, L. (2006). Corruption and pro-poor growth outcomes: Evidence and lessons for African countries. Working Paper Series No. 120, Political Economy Research Instituted.

Negin, V, Rashid, ZBA, and Nikopour, H. (2010). 'The causal relationship between corruption and poverty: A panel data analysis', Working Paper Series.

Persson, Torsten, and Guido T. (1994). "Is Inequality Harmful for Growth?," American Economic Review, Vol. 84 (June), pp. 600 - 621.

Pesaran, M. H., Shin, Y., Smith, R. J., (2001). Bounds Testing Approaches to the Analysis of Level Relationships. Journal of Applied Econometrics 16, 289-326.

Phillips, P. C. B., \& Perron, P. (1988). Testing for a unit root in time series regression. Biometrica, 75, 335-446.

Ravallion and Shaohua C. (1997). "What Can New Survey Data Tell Us About Recent changes in Distribution and Poverty?, "World Bank Economic Review, Vol 1 l(May), No. 2, pp. 357-382.

Ravallion, Martin. (1997). "Can High-Inequality Developing Countries Escape Absolute Poverty?" Economics Letters, Vol. 56 (September), pp. 51-57.

Rose-Ackerman, S. (1978). Corruption: A Study in Political Economy. NY: Academic Press.

Rothstein, B. and Holberg, S. (2011). Correlates of Corruption. The Quality of Government Institute (QoG).http://www.qog.pol.gu.se/digitalAssets/1 $357 / 1357840$.

Shahbaz, M., (2012b). Multivariate-based Granger causality between financial deepening and poverty: The case of Pakistan. Paper presented, 13th Annual Research Conference on "Population Wellbeing: A Development Imperative" was held at Institute of Business Administration (IBA), Karachi (Pakistan).

Tanzi, V. (1998) "Corruption Around the World: Causes, Consequences, Scope, and Cures," IMF Staff Papers, 45: 559-594. 
TI (Transparency International Organization). http://www.transparency.org

Uddin, G.S., Shahbaz, M., Arouri, M.E. and Teulon, F. (2013). Financial Development and poverty Reduction Nexus: A Cointegration and Causality Analysis in Bangladesh. MPRA Paper No. 49264.

Vahideh, N., Zakariah, A. and Hesam, N. (2010): The Causal Relationship between Corruption and Poverty: A Panel Data Analysis. MPRA Paper No. 24871.

Wei, S. (2000). How taxing is corruption on international investors? Review of Economics and Statistics, 52(1), 1-11.

Wickerg, S. (2012). Review of Literature on the Link between Corruption, Poverty and Conflict, and Evidence of the Impact of Corruption on Donor Interventions. Transparency International.

World Bank (2001). World Development Report, 2001: The State in a Changing World.

Yaru and Aminu, M. (2009). Economic perspective of corruption in public sector: A theoretical explanation and lessons for Nigeria. Ilorin Journal of Business and Social Sciences, 13, 143-145.

You, J., and, Khagram, S. (2005). A Comparative Study of Inequality and Corruption. American Sociological Review 70(1):136-157. 